\title{
Extruded soybean meal increased feed intake and milk production in dairy cows
}

\author{
F. Giallongo, ${ }^{*}$ J. Oh, ${ }^{*}$ T. Frederick, ${ }^{*}$ B. Isenberg, ${ }^{*}$ D. M. Kniffen, ${ }^{*}$ R. A. Fabin,† and A. N. Hristov ${ }^{* 1}$ \\ *Department of Animal Science, The Pennsylvania State University, University Park 16802 \\ †Fabin Bros. Farms, Indiana, PA 15701
}

\begin{abstract}
The objective of this study was to assess the effects of 2 extruded soybean meals (ESBM) processed at 2 extruder temperatures, $149^{\circ} \mathrm{C}$ (LTM) and $171^{\circ} \mathrm{C}$ (HTM), on performance, nutrient digestibility, milk fatty acid and plasma amino acid profiles, and rumen fermentation in lactating dairy cows. Nine multiparous Holstein cows were included in a replicated $3 \times 3$ Latin square design experiment with three 28 -d periods. The control diet contained 13\% solvent-extracted soybean meal (SSBM; $53.5 \%$ crude protein with $74.1 \%$ ruminal degradability and $1.8 \%$ fat), which was replaced with equivalent amount (dry matter basis) of LTM $(46.8 \%$, $59.8 \%$, and $10.0 \%)$ or $\operatorname{HTM}(46.9 \%, 41.1 \%$, and $10.9 \%$, respectively) ESBM in the 2 experimental diets (LTM and HTM, respectively). The diets met or exceeded the nutrient requirements of the cows for net energy of lactation and metabolizable protein. The 2 ESBM diets increased dry matter intake and milk yield compared with SSBM. Feed efficiency and milk composition were not affected by treatment. Milk protein yield tended to be increased by ESBM compared with SSBM. Milk urea $\mathrm{N}$ and urinary urea $\mathrm{N}$ excretions were increased by the ESBM diets compared with SSBM. Concentration of fatty acids with chain length of up to C17 and total saturated fatty acids in milk fat were generally decreased and that of $\mathrm{C} 18$ and total mono- and polyunsaturated fatty acids was increased by the ESBM diets compared with SSBM. Blood plasma concentrations of His, Leu, and Val were increased by HTM compared with LTM and SSBM. Plasma concentration of Met was decreased, whereas that of carnosine was increased by the ESBM diets. Treatments had no effect on rumen fermentation, but the proportion of Fibrobacter spp. in whole ruminal contents was increased by HTM compared with SSBM and LTM. Overall, data from this
\end{abstract}

Received May 6, 2015.

Accepted June 5, 2015.

${ }^{1}$ Corresponding author: anh13@psu.edu crossover experiment suggest that substituting SSBM with ESBM in the diet has a positive effect on feed intake and milk yield in dairy cows.

Key words: extruded soybean meal, feed intake, milk fatty acid, dairy cow

\section{INTRODUCTION}

Microbial protein synthesized in the rumen and feed RUP are the main sources of AA for dairy cows (NRC, 2001), and their AA composition is becoming increasingly important when cows are fed diets supplying MP close to or below their requirements. We have demonstrated, for example, that AA such as His may become limiting in dairy cows fed MP below NRC (2001) requirements, partially due to the relatively lower concentration of His in microbial protein, compared with other EAA such as Met (Lee et al., 2012). Even if MP requirements are met, milk production and/or milk protein concentration may be increased by key EAA, through supplementation of the diet with synthetic rumen-protected AA, or digestible RUP from dietary origin (Broderick et al., 2009; Patton et al., 2014). This may be particularly true with alfalfa silagebased diets, which may be high in CP but still supply inadequate amounts of MP and EAA (Broderick et al., 1990; Dhiman et al., 1993). Several heat-treated soybean meal (SBM) products have been developed with the goal of providing a digestible RUP source in the diet. The production responses, however, have been variable (Broderick, 1986; Broderick et al., 1990; Socha, 1991; Flis and Wattiaux, 2005). Most of the commercial heat-treated SBM products have fat content of 1.2 to $2.2 \%$ (Amino Plus, AGP, Omaha, NE; Soy Pass, Ligno Tech USA, Overland Park, KS) up to 6.6\% (SoyPLUS, West Central Cooperative, Ralston, IA; Soy Best, Grain States Soya Inc., West Point, NE). In a preliminary experiment, we analyzed extruded SBM (ESBM) and found a linear increase in its RUP content (determined in situ) with increasing the extruder temperature from $149^{\circ} \mathrm{C}$ to $160^{\circ} \mathrm{C}$ and $171^{\circ} \mathrm{C}$ (Isenberg et al., 2012). The ESBM contained around 10\% fat, which may provide 
additional energy for high-producing dairy cows and may also favorably modify milk FA composition, assuming it does not negatively affect ruminal fermentation and fiber digestibility.

Therefore, the current experiment was conducted to test the effects of $2 \mathrm{ESBM}$ on performance, nutrient digestibility, milk FA and plasma AA profiles, rumen fermentation variables, and bacterial and archaeal composition of ruminal contents in dairy cows. We hypothesized that, when substituting solvent-extracted SBM (SSBM) on an equal-weight basis, ESBM will increase plasma concentrations of key EAA, C18 unsaturated FA in milk, and milk yield or milk protein yield (or both) in dairy cows fed a corn silage-based diet.

\section{MATERIALS AND METHODS}

All procedures carried out in the experiment were approved by the Animal Care and Use Committee at The Pennsylvania State University.

\section{Animals and Experimental Design}

The experiment was a replicated $3 \times 3$ Latin square design balanced for residual effects and was conducted in the tie-stall barn of The Pennsylvania State University's Dairy Teaching and Research Center. Nine multiparous lactating Holstein cows averaging $( \pm \mathrm{SD})$ : $141( \pm 31.0)$ DIM, $41.5( \pm 4.68) \mathrm{kg} / \mathrm{d}$ of milk yield, and $650( \pm 54.7) \mathrm{kg}$ of BW at the beginning of the study, were grouped into 3 squares based on DIM, milk yield, and parity. Six cows (2 squares) were fitted with 10-cm (internal diameter) soft plastic ruminal cannulas (Bar Diamond Inc., Parma, ID). Each experimental period lasted $28 \mathrm{~d}$, with 18 to $21 \mathrm{~d}$ of adaptation to the diets, followed by 10 (DMI, BW, and milk yield and composition) or 7 (all other variables) days of data and sample collection. Cows were randomly assigned to 1 of 3 treatment diets (Table 1), which contained $13 \%$ of (DM basis) (1) SSBM (Cargill Inc., Roaring Spring, PA), (2) low-temperature $\left(149^{\circ} \mathrm{C}\right)$ extruded SBM (LTM), or (3) high-temperature $\left(171^{\circ} \mathrm{C}\right)$ extruded SBM (HTM). The extruded SBM were produced by Fabin Bros. Farms (Indiana, PA). Composition of the SBM used in the experiment is shown in Table 2. Diets were formulated to meet or exceed the NRC (2001) nutrient requirements for lactating Holstein cows yielding $41 \mathrm{~kg}$ of milk/d with $3.50 \%$ milk fat and $3.04 \%$ true protein at 25.5 $\mathrm{kg} / \mathrm{d}$ of DMI and $638 \mathrm{~kg}$ of BW. The $2 \mathrm{ESBM}$ diets were supplemented with $0.35 \%$ of urea (DM basis, replacing corn grain) to achieve a similar $\mathrm{N}$ concentration to the SSBM diet, and because of the lower RDP content of the 2 ESBM compared with SSBM (see Table 1). The
3 diets were mixed using a Kuhn Knight model 3142 Reel Auggie Mixer Wagon (Kuhn Knight Inc., Brodhead, WI) and were fed once daily (0630 h) as TMR to achieve about 5 to $10 \%$ refusals. All cows had free access to drinking water, were milked twice daily (0500 and $1700 \mathrm{~h}$ ), and received rbST (Posilac, Elanco Co., Greenfield, IN; $500 \mathrm{mg}$, i.m.) at 14-d intervals (i.e., at the beginning and in the middle of each experimental period).

\section{Sampling and Measurements}

Individual feed intake (on as-fed basis) and milk yield of the cows were recorded daily throughout the experiment. Cow BW was also recorded daily for the entire experiment using AfiFarm 3.04E scale system (S.A.E. Afikim, Rehovot, Israel) while cows exited the milk parlor. Total mixed ration and refusals from each diet were sampled twice weekly, and samples were composited (on an equal weight basis) by week and diet. Samples of individual forages (i.e., corn silage, alfalfa haylage, and grass hay) and concentrate feeds were collected weekly. Forages were composited by experimental period, whereas one composite sample for the entire experiment was prepared for each concentrate feed ingredient. All samples were stored at $-20^{\circ} \mathrm{C}$, dried for $\mathrm{DM}$ determination at $65^{\circ} \mathrm{C}$ for $48 \mathrm{~h}$ in a forced-air oven, and ground with a Wiley Mill (1-mm screen; Thomas Scientific, Swedesboro, NJ) for further analyses. Dry matter intake was computed from the as-fed TMR intake using the DM content of the weekly composited TMR and refusals samples. Composite samples of individual feed ingredients were analyzed by wet chemistry methods for CP, degradable protein (SSBM and ESBM only; according to Krishnamoorthy et al., 1983), NDF, ADF, fat, ash, Ca, P, and estimated NFC and NEL by Cumberland Valley Analytical Services (Maugansville, MD; analytical methods are available from CVAS, 2015). The analyzed composition of the feed ingredients and their inclusion in the TMR was used to compute the $\mathrm{CP}, \mathrm{NDF}, \mathrm{ADF}$, fat, $\mathrm{Ca}$, and $\mathrm{P}$ concentration of the diets (Table 1). Concentration of RDP, RUP, $\mathrm{NE}_{\mathrm{L}}$, NFC and MP, protein fractions, and AA balances were estimated using NRC (2001) based on actual DMI, milk yield, milk composition, and BW of the cows during the experiment. Composite TMR samples were analyzed for starch according to Bach Knudsen (1997) and indigestible NDF (iNDF) as described by Lee et al. (2012). Samples of the 3 SBM (i.e., SSBM, LTM, and HTM) were also analyzed for AA (AOAC International, 2006, method no. 982.30 E) at the University of MissouriColumbia's Agricultural Experiment Station Chemical Laboratory (Columbia, MO). 
Table 1. Ingredients and chemical composition of the diets and protein and AA balance during the experiment

\begin{tabular}{|c|c|c|c|}
\hline \multirow[b]{2}{*}{ Item } & \multicolumn{3}{|c|}{ Diet $^{1}$} \\
\hline & SSBM & LTM & HTM \\
\hline \multicolumn{4}{|l|}{ Ingredient, $\%$ of DM } \\
\hline Corn silage $^{2}$ & 40.0 & 40.0 & 40.0 \\
\hline Alfalfa haylage ${ }^{3}$ & 20.0 & 20.0 & 20.0 \\
\hline Grass hay ${ }^{4}$ & $\begin{array}{r}5.0 \\
5.0\end{array}$ & $\begin{array}{r}20.0 \\
5.0\end{array}$ & 5.0 \\
\hline Cottonseed, hulls & 5.0 & 5.0 & 5.0 \\
\hline Corn grain, ground & 9.00 & 8.65 & 8.65 \\
\hline SBM, solvent-extracted & 13.0 & - & - \\
\hline SBM, extruded & - & 13.0 & 13.0 \\
\hline Urea & - & 0.35 & 0.35 \\
\hline Molasses $^{5}$ & 5.0 & 5.0 & 5.0 \\
\hline Mineral/vitamin premix ${ }^{6}$ & 2.8 & 2.8 & 2.8 \\
\hline Salt & 0.2 & 0.2 & 0.2 \\
\hline \multicolumn{4}{|l|}{ Composition, $\%$ of DM } \\
\hline $\mathrm{CP}^{7}$ & 16.0 & 16.0 & 16.0 \\
\hline $\mathrm{RDP}^{8}$ & 10.0 & 9.7 & 8.8 \\
\hline RUP $^{8}$ & 5.9 & 6.2 & 7.1 \\
\hline $\mathrm{NDF}^{7}$ & 33.4 & 33.5 & 33.6 \\
\hline $\mathrm{ADF}^{7}$ & 22.5 & 22.5 & 22.5 \\
\hline Fat $^{7}$ & $\begin{array}{l}3.09 \\
3.09\end{array}$ & 4.23 & 4.35 \\
\hline $\operatorname{Starch}^{9}$ & 20.5 & 20.4 & 20.4 \\
\hline $\mathrm{NE}_{\mathrm{T}}^{8} \mathrm{Mcal} / \mathrm{kg}$ & 1.49 & 1.51 & 1.51 \\
\hline $\mathrm{NE}_{\mathrm{J}}$ balance, ${ }^{8} \mathrm{Mcal} / \mathrm{d}$ & 3.9 & 5.5 & 5.1 \\
\hline $\mathrm{NFC}^{10}$ & 44.0 & 42.7 & 42.5 \\
\hline $\mathrm{Ca}^{7}$ & 0.81 & 0.81 & 0.81 \\
\hline $\mathrm{P}^{7}$ & 0.32 & 0.33 & 0.33 \\
\hline \multicolumn{4}{|c|}{ Protein and AA balance, ${ }^{8,11} \mathrm{~g} / \mathrm{d}$} \\
\hline \multicolumn{4}{|l|}{ MP } \\
\hline Requirements & 2,588 & 2.723 & 2,735 \\
\hline Supply & 2,845 & 3,091 & 3,200 \\
\hline \multirow{2}{*}{\multicolumn{4}{|c|}{$\begin{array}{l}\text { Balance } \\
\text { RDP and RUP }\end{array}$}} \\
\hline & & & \\
\hline RDP supply & 2.669 & 2.754 & 2,494 \\
\hline RDP balance & 124 & 42 & -212 \\
\hline RUP supply & 1,592 & 1,760 & 2,006 \\
\hline RUP balance & 306 & 437 & 546 \\
\hline \multicolumn{4}{|l|}{ dMet } \\
\hline Requirements $^{12}$ & 57 & 60 & 60 \\
\hline Supply & 49 & 53 & 53 \\
\hline Balance & -8 & -7 & -7 \\
\hline \multicolumn{4}{|l|}{ dLys } \\
\hline Requirements ${ }^{12}$ & 171 & 180 & 181 \\
\hline Supply & 183 & 197 & 195 \\
\hline Balance & 12 & 17 & 14 \\
\hline \multicolumn{4}{|l|}{ dHis } \\
\hline Requirements ${ }^{12}$ & 57 & 60 & 60 \\
\hline Supply & 58 & 63 & 65 \\
\hline Balance & 1 & 3 & 5 \\
\hline
\end{tabular}

${ }^{1} \mathrm{SSBM}=$ solvent-extracted $\mathrm{SBM} ; \mathrm{LTM}=\mathrm{SBM}$ extruded at $149^{\circ} \mathrm{C} ; \mathrm{HTM}=\mathrm{SBM}$ extruded at $171^{\circ} \mathrm{C}$.

${ }^{2}$ Corn silage was $40.9 \% \mathrm{DM}$ and (DM basis): $36.7 \% \mathrm{NDF}$ and $8.1 \% \mathrm{CP}$.

${ }^{3}$ Alfalfa haylage was $45.2 \% \mathrm{DM}$ and (DM basis): $42.4 \% \mathrm{NDF}$ and $18.6 \% \mathrm{CP}$.

${ }^{4}$ Grass hay contained (DM basis): $74.0 \% \mathrm{NDF}$ and $7.1 \% \mathrm{CP}$.

${ }^{5}$ Molasses (Westway Feed Products, Tomball, TX) contained (DM basis) $3.9 \% \mathrm{CP}$ and $66 \%$ total sugar.

${ }^{6}$ The premix (Cargill Animal Nutrition, Cargill Inc., Roaring Spring, PA) contained (\%, as-is basis) trace mineral mix, 0.86; $\mathrm{MgO}(56 \% \mathrm{Mg}), 8.0 ; \mathrm{NaCl}, 6.4$; vitamin ADE premix (Cargill Animal Nutrition, Cargill Inc.), 0.48; limestone, 37.2; selenium premix (Cargill Animal Nutrition, Cargill Inc.), 0.07; and dry corn distillers grains with solubles, 46.7. Ca, 14.1\%; P, 0.39\%; Mg, 4.59\%; K, 0.44\%; S, 0.39\%; Se, $6.91 \mathrm{mg} / \mathrm{kg}$; Cu, $362 \mathrm{mg} /$ $\mathrm{kg} ; \mathrm{Zn}, 1,085 \mathrm{mg} / \mathrm{kg} ; \mathrm{Fe}, 186 \mathrm{mg} / \mathrm{kg}$, vitamin A, 276,717 IU/kg; vitamin D, 75,000 IU/kg; and vitamin E, $1,983 \mathrm{IU} / \mathrm{kg}$.

${ }^{7}$ Values calculated using the chemical analysis (Cumberland Valley Analytical Services Inc., Maugansville, $\mathrm{MD}$ ) of individual feed ingredients of the diet.

${ }^{8}$ All values were estimated based on NRC (2001) using actual DMI, milk yield, milk composition, and BW of the cows throughout the trial.

${ }^{9}$ Values determined using an enzymatic colorimetric method (Bach Knudsen, 1997) on TMR composites.

${ }^{10}$ Estimated by NRC (2001).

${ }^{11} \mathrm{dLys}$, dMet, dHis = digestible Lys, Met, and His, respectively. Due to rounding, balance may not exactly match requirements and supply.

${ }^{12}$ Requirements of dLys and dMet were calculated as 6.6 and $2.2 \%$ (respectively) of MP requirements (Schwab et al., 2005). Requirements of dHis were assumed as $2.2 \%$ of MP requirements (Lee et al., 2012). 
Table 2. Crude protein, fat, and AA concentration of the soybean meals (SBM) fed in the experiment

\begin{tabular}{lccc}
\hline & & Soybean meal $^{1}$ & \\
\cline { 2 - 4 } Item & SSBM & LTM & HTM \\
\hline CP, ${ }^{2} \%$ DM & 53.5 & 46.8 & 46.9 \\
RDP, \% of CP & 74.1 & 59.8 & 41.1 \\
RUP, \% of CP & 25.9 & 40.2 & 58.9 \\
Crude fat, \% DM & 1.82 & 10.0 & 10.9 \\
EAA, \% CP & & & \\
Arg & 7.17 & 6.91 & 6.90 \\
His & 2.49 & 2.38 & 2.40 \\
Ile & 4.45 & 4.35 & 4.29 \\
Leu & 7.96 & 7.66 & 7.76 \\
Lys & 6.47 & 6.43 & 6.22 \\
Met & 1.44 & 1.42 & 1.45 \\
Phe & 5.19 & 5.01 & 5.08 \\
Thr & 3.85 & 3.80 & 3.85 \\
Trp & 1.46 & 1.33 & 1.41 \\
Val & 4.58 & 4.44 & 4.40 \\
Total EAA & 45.1 & 43.7 & 43.8 \\
NEAA, \% CP & & & \\
Ala & 4.18 & 4.28 & 4.37 \\
Asp & 11.2 & 10.8 & 11.0 \\
Cys & 1.32 & 1.35 & 1.38 \\
Glu & 17.8 & 17.0 & 17.2 \\
Gly & 3.87 & 4.12 & 4.09 \\
Pro & 4.95 & 4.99 & 4.97 \\
Ser & 4.43 & 4.44 & 4.46 \\
Tyr & 3.52 & 3.48 & 3.50 \\
Total NEAA & 51.3 & 50.5 & 51.0 \\
\hline SSM = & & & \\
\hline
\end{tabular}

${ }^{1} \mathrm{SSBM}=$ solvent-extracted $\mathrm{SBM} ; \mathrm{LTM}=\mathrm{SBM}$ extruded at $149^{\circ} \mathrm{C} ; \mathrm{HTM}=\mathrm{SBM}$ extruded at $171^{\circ} \mathrm{C}$.

${ }^{2} \mathrm{~N} \times 6.25$.

${ }^{3}$ Estimated using the Streptomyces griseus protease method (Krishnamoorthy et al., 1983) by Cumberland Valley Analytical Services (Maugansville, MD).

During the last week of each experimental period, 8 spot fecal and urine samples (approximately $500 \mathrm{~g}$ and $300 \mathrm{~mL} /$ sample, respectively) were collected in 3 consecutive days at intervals staggered in time to cover a 24 -h period. Fecal samples were oven-dried at $65^{\circ} \mathrm{C}$ for $48 \mathrm{~h}$, ground through a 1-mm sieve, composited per cow and experimental period, and then analyzed for starch (Bach Knudsen, 1997) and DM, OM, CP, NDF, ADF, and iNDF as described in Lee et al. (2012). Total-tract apparent digestibility of DM, OM, NDF, $\mathrm{ADF}, \mathrm{CP}$, and starch was estimated using iNDF as an internal digestibility marker. Urine samples were processed and analyzed for allantoin, uric acid, creatinine, urea-N, and total $\mathrm{N}$ as described by Lee et al. (2012). Daily urine volume was calculated using creatinine as a marker, assuming a creatinine excretion rate of 29 $\mathrm{mg} / \mathrm{kg}$ of BW (Hristov et al., 2011), and was used to estimate urinary $\mathrm{N}$ and purine derivative excretions.

Blood samples were collected from the tail vein or artery into heparinized vacutainers at 2 and $4 \mathrm{~h}$ after feeding on d 24 and 25 of each experimental period. Blood plasma was separated and processed (Lee et al., 2012) for analysis of urea N (Stanbio Urea Nitrogen Kit
0580, Stanbio Laboratory Inc., Boerne, TX), AA, and the dipeptides carnosine and anserine at the University of Missouri-Columbia's Agricultural Experiment Station Chemical Laboratory following the procedures of Deyl et al. (1986) and Fekkes (1996).

Milk samples were collected from 2 consecutive milkings (p.m. and a.m.) in 3 separate days (d 20 and 21, 24 and 25, and 27 and 28) during each experimental period. Milk samples were preserved with 2-bromo2-nitropropane-1,3 diol and submitted to Dairy One Laboratory (Pennsylvania DHIA, University Park, PA) for analysis of fat, true protein, lactose, and MUN using infrared spectroscopy (MilkoScan 4000, Foss Electric, Hillerød, Denmark). Evening and morning milk samples were analyzed separately so milk component concentration could be weighed for p.m and a.m. milk yields. A separate unpreserved milk sample was collected during wk 4 of each experimental period and stored at $-20^{\circ} \mathrm{C}$ for FA composition analysis as described elsewhere (Hristov et al., 2010).

Samples of whole ruminal contents were collected from the cannulated cows at 2, 4, and $6 \mathrm{~h}$ after feeding on d 27 and 28 of each experimental period. These 
samples were collected, processed, and analyzed for $\mathrm{pH}$, ammonia, VFA, and bacteria and archaeal order and genus composition as described in Hristov et al. (2013a), with the exception that samples for microbial composition were stored at $-80^{\circ} \mathrm{C}$ before analysis.

A subexperiment was conducted to determine in situ ruminal degradability of $\mathrm{CP}$ of the $3 \mathrm{SBM}$ products (i.e., SSBM, LTM, and HTM). The experimental procedures were as described by Lee et al. (2012), except 2 cows were used for the rumen incubation; $7 \mathrm{~g}$ of SBM per bag was incubated in the rumen of the cows in triplicate for $0,2,4,8,24$, and $48 \mathrm{~h}$; and bags with in situ residues were dried at $65^{\circ} \mathrm{C}$ for $48 \mathrm{~h}$. The cows used in the in situ experiment were fed (\% of DM): corn silage, 43; grass hay, 7.9; ground corn grain, 9.9; canola meal, 8.0; whole roasted soybeans, 7.9; SoyPLUS (West Central Cooperative, Ralston, IA), 6.9; bakery byproduct meal, 6.0; cottonseed hulls, 3.8; molasses, 3.4; and a mineral and vitamin premix, 3.2. Aliquots of each in situ bag residue was pulverized using a Mixer Mill MM 200 (Retsch GmbH, Haan, Germany) and analyzed for $\mathrm{N}$ using elemental analyzer (Costech ECS $4010 \mathrm{C} / \mathrm{N} / \mathrm{S}$, Costech Analytical Technologies Inc., Valencia, CA) to calculate $\mathrm{CP}(\mathrm{N} \times 6.25)$. Rumen-degraded protein and RUP values of the SSBM, LTM, and HTM products were estimated using NRC (2001) equations.

Another subexperiment was conducted to evaluate the heat stability of SSBM Lys. A single sample of the SSBM used in the main experiment was heated in a forced-air oven to temperatures ranging from $100^{\circ} \mathrm{C}$ to $200^{\circ} \mathrm{C}$ in $20^{\circ} \mathrm{C}$ intervals for $1 \mathrm{~h}$ and was analyzed for Lys as described above.

\section{Statistical Analysis}

All data were analyzed using the MIXED procedure of SAS (2003, SAS Institute Inc., Cary, NC). Milk yield, DMI, and BW data for the last $10 \mathrm{~d}$ of each experimental period were averaged and the average values were used in the statistical analysis. Feed efficiency (milk yield $\div$ DMI) was estimated based on the average milk yield and DMI data. Milk composition data were also averaged per cow, and experimental period and the average values were used in the statistical analysis. The statistical model included treatment and experimental period. Square and cow within square were random effects and all others were fixed.

Data from the in situ experiment were analyzed using the NLMIXED procedure of SAS. Degradability data for replicated bags incubated in each cow at each time point were averaged and the average values were used in the statistical analysis. In situ degradability parameters [soluble N, fraction a; potentially degradable fraction, fraction b; rate of degradation (disappearance) of the degradable fraction, c; and effective degradability in the rumen, ED] were estimated according to the models of Ørskov and McDonald (1979) using dummy variable technique for treatment comparisons and contrasts (PROC NLMIXED; adjusted $\mathrm{R}^{2}$ was 0.98 to 0.99). A passage rate of $0.06 / \mathrm{h}$ was used to estimate ED.

When the main effect of treatment was significant, means were separated by pairwise $t$-test (pdiff option of PROC MIXED). Statistical differences were considered significant at $P \leq 0.05$ and a trend at $0.05 \leq P \leq 0.10$. Data in tables are presented as least squares means.

\section{RESULTS}

The nutrient composition of the 3 diets was similar (Table 1) with the exception that fat concentration was higher with the LTM and HTM diets compared with SSBM because of the higher fat content of ESBM versus SSBM (around 10 vs. 1.8\%). The 3 diets provided $\mathrm{NE}_{\mathrm{L}}, \mathrm{MP}, \mathrm{RDP}$ (except the HTM diet), and RUP in excess of the estimated (NRC, 2001) cow requirements. The diets were about 14, 12, and 12\% (SSBM, LTM, and HTM, respectively) deficient in digestible Met, according to Schwab et al. (2005). All 3 diets supplied adequate amounts of digestible Lys and His, according Schwab et al. (2005) and Lee et al. (2012), respectively.

The CP concentration of the SSBM was higher compared with the ESBM as a result of its lower fat content (Table 2). As expected, the proportion of RDP in CP was higher for SSBM, whereas HTM had the highest proportion of RUP. Concentrations of Arg, His, and Trp were about 4 to $6 \%$ lower for ESBM compared with SSBM. Concentration of Lys was also about $4 \%$ lower for HTM compared with SSBM. Overall, concentrations of most EAA, except Met and Thr, were slightly decreased in ESBM versus SSBM. Of the NEAA, Gly concentration was about $6 \%$ higher for ESBM versus SSBM.

Dry matter intake, milk and lactose yields, and MUN were increased $(P \leq 0.05)$ by LTM and HTM, compared with SSBM (Table 3). Milk protein yield tended $(P=$ 0.09) to be higher for the ESBM diets versus SSBM. Concentration of plasma urea $\mathrm{N}$ was increased $(P=$ 0.03) for LTM compared with SSBM. No differences among treatments were observed $(P>0.10)$ for feed efficiency, milk fat, protein, and lactose concentrations and milk fat, $\mathrm{ECM}$, and milk $\mathrm{NE}_{\mathrm{L}}$ yields.

Intake of all nutrients during the digestibility measurement periods was $(P \leq 0.05)$ or tended $(P=0.06$ for $\mathrm{OM}$ and starch) to be increased by the ESBM diets compared with SSBM (Table 4). Apparent total-tract digestibilities of DM, OM, and ADF were slightly 
Table 3. Dry matter intake and milk production variables in dairy cows fed diets containing solvent-extracted or extruded soybean meals (SBM)

\begin{tabular}{|c|c|c|c|c|c|}
\hline \multirow[b]{2}{*}{ Item } & \multicolumn{3}{|c|}{$\operatorname{Diet}^{1}$} & \multirow[b]{2}{*}{$\mathrm{SEM}^{2}$} & \multirow[b]{2}{*}{$P$-value } \\
\hline & SSBM & LTM & HTM & & \\
\hline DMI, $\mathrm{kg} / \mathrm{d}$ & $26.9^{\mathrm{b}}$ & $28.2^{\mathrm{a}}$ & $28.1^{\mathrm{a}}$ & 1.49 & 0.05 \\
\hline Milk yield, $\mathrm{kg} / \mathrm{d}$ & $37.5^{\mathrm{b}}$ & $40.6^{\mathrm{a}}$ & $40.9^{\mathrm{a}}$ & 2.21 & 0.01 \\
\hline Milk yield $\div$ DMI, $\mathrm{kg} / \mathrm{kg}$ & 1.43 & 1.44 & 1.49 & 0.062 & 0.28 \\
\hline Milk fat, $\%$ & 3.60 & 3.38 & 3.42 & 0.16 & 0.23 \\
\hline Milk fat, $\mathrm{kg} / \mathrm{d}$ & 1.34 & 1.37 & 1.40 & 0.065 & 0.68 \\
\hline Milk true protein, $\%$ & 2.95 & 2.90 & 2.86 & 0.053 & 0.23 \\
\hline Milk true protein, $\mathrm{kg} / \mathrm{d}$ & 1.11 & 1.17 & 1.17 & 0.053 & $0.09^{3}$ \\
\hline Milk lactose, \% & 4.71 & 4.72 & 4.71 & 0.062 & 0.93 \\
\hline Milk lactose, $\mathrm{kg} / \mathrm{d}$ & $1.77^{\mathrm{b}}$ & $1.92^{\mathrm{a}}$ & $1.93^{\mathrm{a}}$ & 0.10 & 0.04 \\
\hline MUN, mg/dL & $13.1^{\mathrm{b}}$ & $14.7^{\mathrm{a}}$ & $14.8^{\mathrm{a}}$ & 0.47 & $<0.01$ \\
\hline $\mathrm{ECM},{ }^{4} \mathrm{~kg} / \mathrm{d}$ & 34.5 & 36.2 & 36.5 & 1.64 & 0.25 \\
\hline $\mathrm{ECM} \div \mathrm{DMI}, \mathrm{kg} / \mathrm{kg}$ & 1.29 & 1.29 & 1.31 & 0.046 & 0.74 \\
\hline Milk $\mathrm{NE}_{\mathrm{L}},{ }^{5} \mathrm{Mcal} / \mathrm{d}$ & 25.7 & 27.0 & 27.2 & 1.22 & 0.26 \\
\hline $\mathrm{BW}, \mathrm{kg}$ & 625 & 645 & 631 & 24.4 & 0.81 \\
\hline $\mathrm{PUN},{ }^{6} \mathrm{mg} / \mathrm{dL}$ & $10.3^{\mathrm{b}}$ & $12.6^{\mathrm{a}}$ & $11.7^{\mathrm{ab}}$ & 0.76 & 0.03 \\
\hline
\end{tabular}

a,b Means with different letter superscripts differ at $P<0.05$.

${ }^{1} \mathrm{SSBM}=$ solvent-extracted $\mathrm{SBM} ; \mathrm{LTM}=\mathrm{SBM}$ extruded at $149^{\circ} \mathrm{C} ; \mathrm{HTM}=\mathrm{SBM}$ extruded at $171^{\circ} \mathrm{C}$.

${ }^{2}$ Largest SEM published in table; $\mathrm{n}=26$ ( $\mathrm{n}$ represents number of observations used in the statistical analysis). Data are presented as LSM.

${ }^{3}$ SSBM vs. LTM, $P<0.05$.

${ }^{4}$ Energy-corrected milk $(\mathrm{kg} / \mathrm{d})=\mathrm{kg}$ of milk $\times[(38.3 \times \%$ fat $\times 10+24.2 \times \%$ true protein $\times 10+16.54 \times$ $\%$ lactose $\times 10+20.7) \div 3,140]$ (Sjaunja et al., 1990).

${ }^{5}$ Milk $\mathrm{NE}_{\mathrm{L}}(\mathrm{Mcal} / \mathrm{d})=\mathrm{kg}$ of milk $\times(0.0929 \times \%$ fat $+0.0563 \times \%$ true protein $+0.0395 \times \%$ lactose $)(\mathrm{NRC}$, 2001).

${ }^{6}$ Plasma urea N.

Table 4. Nutrient intake and total-tract apparent digestibility in dairy cows fed diets containing solventextracted or extruded soybean meals (SBM)

\begin{tabular}{lccccc}
\hline & \multicolumn{3}{c}{ Diet $^{1}$} & & \\
\cline { 2 - 3 } Item & SSBM & LTM & HTM & SEM $^{2}$ & $P$-value \\
\hline Nutrient intake, ${ }^{3} \mathrm{~kg} / \mathrm{d}$ & & & & & \\
DM & $26.9^{\mathrm{b}}$ & $28.2^{\mathrm{a}}$ & $28.0^{\mathrm{a}}$ & 1.15 & 0.05 \\
OM & 25.1 & 26.3 & 26.1 & 1.08 & 0.06 \\
NDF & $8.98^{\mathrm{b}}$ & $9.45^{\mathrm{a}}$ & $9.42^{\mathrm{a}}$ & 0.38 & 0.03 \\
ADF & $6.05^{\mathrm{b}}$ & $6.35^{\mathrm{a}}$ & $6.31^{\mathrm{a}}$ & 0.26 & 0.05 \\
CP & $4.30^{\mathrm{b}}$ & $4.51^{\mathrm{a}}$ & $4.49^{\mathrm{a}}$ & 0.18 & 0.05 \\
Starch & 5.50 & 5.77 & 5.72 & 0.23 & 0.06 \\
Apparent digestibility, $\%$ & & & & & \\
DM & $64.0^{\mathrm{ab}}$ & $63.4^{\mathrm{b}}$ & $64.7^{\mathrm{a}}$ & 0.32 & $0.01^{4}$ \\
OM & $65.3^{\mathrm{ab}}$ & $64.7^{\mathrm{b}}$ & $65.7^{\mathrm{a}}$ & 0.33 & $0.03^{5}$ \\
NDF & 39.3 & 38.2 & 39.4 & 0.80 & 0.45 \\
ADF & $37.4^{\mathrm{ab}}$ & $36.7^{\mathrm{b}}$ & $39.1^{\mathrm{a}}$ & 0.81 & $0.04^{6}$ \\
CP & 64.7 & 63.0 & 64.1 & 1.14 & 0.50 \\
Starch & $97.5^{\mathrm{a}}$ & $96.9^{\mathrm{b}}$ & $96.8^{\mathrm{b}}$ & 0.24 & 0.01 \\
\hline
\end{tabular}

${ }_{\mathrm{a}, \mathrm{b}}$ Means with different letter superscripts differ at $P<0.05$.

${ }^{1} \mathrm{SSBM}=$ solvent-extracted $\mathrm{SBM} ; \mathrm{LTM}=\mathrm{SBM}$ extruded at $149^{\circ} \mathrm{C} ; \mathrm{HTM}=\mathrm{SBM}$ extruded at $171^{\circ} \mathrm{C}$.

${ }^{2}$ Largest SEM published in table; $\mathrm{n}=26$ ( $\mathrm{n}$ represents number of observations used in the statistical analysis).

Data are presented as LSM.

${ }^{3}$ Intake data during the digestibility measurement periods.

${ }^{4} \mathrm{SSBM}$ vs. LTM, $P=0.09$; SSBM vs. HTM, $P=0.10$.

${ }^{5} \mathrm{SSBM}$ vs. LTM, $P=0.08$.

${ }^{6} \mathrm{SSBM}$ vs. HTM, $P=0.07$. 
Table 5. Milk FA composition (g/100 g of total FA) in dairy cows fed diets containing solvent-extracted or extruded soybean meals (SBM)

\begin{tabular}{|c|c|c|c|c|c|}
\hline \multirow[b]{2}{*}{ Fatty acid } & \multicolumn{3}{|c|}{$\operatorname{Diet}^{1}$} & \multirow[b]{2}{*}{$\mathrm{SEM}^{2}$} & \multirow[b]{2}{*}{$P$-value } \\
\hline & SSBM & LTM & нТм & & \\
\hline 4:0 & 3.99 & 4.14 & 4.04 & 0.143 & 0.39 \\
\hline $6: 0$ & 2.35 & 2.30 & 2.25 & 0.079 & 0.38 \\
\hline $8: 0$ & $1.41^{\mathrm{a}}$ & $1.31^{\mathrm{b}}$ & $1.28^{\mathrm{b}}$ & 0.052 & 0.02 \\
\hline 10:0 & $3.40^{\mathrm{a}}$ & $2.92^{\mathrm{b}}$ & $2.86^{\mathrm{b}}$ & 0.148 & $<0.001$ \\
\hline $12: 0$ & $3.84^{\mathrm{a}}$ & $3.16^{\mathrm{b}}$ & $3.09^{\mathrm{b}}$ & 0.151 & $<0.001$ \\
\hline 14:0 & $10.9^{\mathrm{a}}$ & $9.97^{\mathrm{b}}$ & $9.89^{\mathrm{b}}$ & 0.197 & $<0.001$ \\
\hline $14: 1$ & $1.16^{\mathrm{a}}$ & $0.95^{\mathrm{b}}$ & $1.00^{\mathrm{b}}$ & 0.091 & $<0.01$ \\
\hline $15: 0$ & $0.90^{\mathrm{a}}$ & $0.75^{\mathrm{b}}$ & $0.78^{\mathrm{b}}$ & 0.025 & $<0.01$ \\
\hline 16:0 & $28.4^{\mathrm{a}}$ & $24.7^{\mathrm{b}}$ & $23.8^{\mathrm{c}}$ & 0.62 & $<0.001$ \\
\hline $16: 1$ & $1.74^{\mathrm{a}}$ & $1.33^{\mathrm{b}}$ & $1.38^{\mathrm{b}}$ & 0.129 & $<0.001$ \\
\hline $17: 0$ & $0.48^{\mathrm{a}}$ & $0.44^{\mathrm{b}}$ & $0.43^{\mathrm{b}}$ & 0.011 & $<0.01$ \\
\hline 18:0 & $8.05^{\mathrm{b}}$ & $9.86^{\mathrm{a}}$ & $9.82^{\mathrm{a}}$ & 0.381 & $<0.001$ \\
\hline $18: 1$, trans -4 & $0.02^{\mathrm{c}}$ & $0.03^{\mathrm{b}}$ & $0.03^{\mathrm{a}}$ & 0.001 & $<0.001$ \\
\hline $18: 1$, trans -5 & $0.02^{\mathrm{b}}$ & $0.03^{\mathrm{a}}$ & $0.03^{\mathrm{a}}$ & 0.001 & $<0.001$ \\
\hline $18: 1$, trans $-6-8$ & $0.30^{\mathrm{b}}$ & $0.44^{\mathrm{a}}$ & $0.47^{\mathrm{a}}$ & 0.016 & $<0.001$ \\
\hline $18: 1$, trans -9 & $0.24^{\mathrm{c}}$ & $0.35^{\mathrm{b}}$ & $0.37^{\mathrm{a}}$ & 0.010 & $<0.001$ \\
\hline $18: 1$, trans -10 & $0.50^{\mathrm{b}}$ & $0.74^{\mathrm{a}}$ & $0.88^{\mathrm{a}}$ & 0.093 & $<0.01$ \\
\hline $18: 1$, trans -11 & $0.93^{\mathrm{c}}$ & $1.57^{\mathrm{b}}$ & $1.75^{\mathrm{a}}$ & 0.071 & $<0.001$ \\
\hline $18: 1$, trans $-10+$ trans -11 & $1.42^{\mathrm{c}}$ & $2.31^{\mathrm{b}}$ & $2.63^{\mathrm{a}}$ & 0.127 & $<0.001$ \\
\hline $18: 1$, cis -9 & $20.9^{\mathrm{b}}$ & $22.6^{\mathrm{a}}$ & $22.5^{\mathrm{a}}$ & 0.796 & 0.04 \\
\hline $18: 1$, cis- 11 & $1.09^{\mathrm{b}}$ & $1.27^{\mathrm{a}}$ & $1.30^{\mathrm{a}}$ & 0.058 & $<0.001$ \\
\hline $18: 2$, cis- 9, cis- 12 & $2.71^{\mathrm{c}}$ & $3.54^{\mathrm{b}}$ & $4.22^{\mathrm{a}}$ & 0.090 & $<0.001$ \\
\hline $18: 3$ & $0.38^{\mathrm{c}}$ & $0.46^{\mathrm{b}}$ & $0.51^{\mathrm{a}}$ & 0.013 & $<0.001$ \\
\hline CLA-cis-9,trans-11 & $0.42^{\mathrm{b}}$ & $0.64^{\mathrm{a}}$ & $0.73^{\mathrm{a}}$ & 0.052 & $<0.001$ \\
\hline CLA-trans- 10, cis- 12 & ND & ND & ND & 0.001 & 0.28 \\
\hline 20:0 & 0.10 & 0.11 & 0.11 & 0.006 & 0.11 \\
\hline Others & $5.33^{\mathrm{b}}$ & $5.66^{\mathrm{a}}$ & $5.82^{\mathrm{a}}$ & 0.118 & $<0.01$ \\
\hline Total trans $\mathrm{FA}$ & $2.46^{\mathrm{c}}$ & $3.82^{\mathrm{b}}$ & $4.22^{\mathrm{a}}$ & 0.162 & $<0.001$ \\
\hline$\Sigma \mathrm{SFA}$ & $63.9^{\mathrm{a}}$ & $59.6^{\mathrm{b}}$ & $58.2^{\mathrm{c}}$ & 1.16 & $<0.001$ \\
\hline$\Sigma$ MUFA & $26.6^{\mathrm{b}}$ & $29.4^{\mathrm{a}}$ & $29.9^{\mathrm{a}}$ & 0.98 & $<0.001$ \\
\hline$\Sigma$ PUFA & $3.09^{\mathrm{c}}$ & $4.00^{\mathrm{b}}$ & $4.73^{\mathrm{a}}$ & 0.100 & $<0.001$ \\
\hline
\end{tabular}

${ }^{\mathrm{a}-\mathrm{c}}$ Means with different letter superscripts differ at $P<0.05$.

${ }^{1} \mathrm{SSBM}=$ solvent-extracted $\mathrm{SBM} ; \mathrm{LTM}=\mathrm{SBM}$ extruded at $149^{\circ} \mathrm{C} ; \mathrm{HTM}=\mathrm{SBM}$ extruded at $171^{\circ} \mathrm{C}$.

${ }^{2}$ Largest SEM published in table; $\mathrm{n}=26$ ( $\mathrm{n}$ represents number of observations used in the statistical analysis); $\mathrm{ND}=$ not detected. Data are presented as LSM.

higher $(P \leq 0.04)$ for HTM versus LTM. Digestibility of starch was about $1 \%$ lower $(P=0.01)$ for the ESBM diets versus SSBM.

Compared with SSBM, the ESBM diets had decreased $(P \leq 0.02)$ concentrations of 8:0, 10:0, 12:0, 14:0, 14:1, 15:0, 16:0, 16:1, and 17:0 FA in milk fat (Table 5). Concentration of 16:0 was decreased $(P<$ $0.05)$ by HTM compared with LTM. On the other hand, concentrations of 18:0, trans- and cis-18:1, cis-9, cis-12, 18:2, 18:3, cis-9,trans-11 CLA, and total trans FA were increased $(P \leq 0.04)$ by the ESBM diets, compared with SSBM. Overall, the ESBM diets resulted in lower concentrations of saturated FA and greater concentrations of MUFA and PUFA $(P<0.001)$ compared with SSBM.

Blood plasma concentrations of His, Leu, Val, and 1-methylhistidine $(\mathbf{1}-\mathbf{M H})$ were increased $(P \leq 0.03)$ by HTM compared with SSBM and LTM (Table 6).
Concentration of Met was decreased $(P=0.05)$ and that of carnosine was increased $(P=0.02)$ by the ESBM diets compared with SSBM. Plasma Ile and Tau concentrations tended to be increased $(P \leq 0.07)$ by the ESBM diets compared with SSBM, whereas plasma Thr tended to be lower $(P=0.07)$ for the ESBM diets. Plasma Lys concentration was not affected by diet. Concentration of Pro was increased $(P=0.02)$ by HTM versus SSBM. Concentration of 3-methylhistidine $(3-\mathbf{M H})$ tended to be lower $(P=0.10)$ for HTM compared with SSBM and LTM.

During the fecal and urine sampling periods, $\mathrm{N}$ intake was higher $(P=0.05)$ and secretion of milk trueprotein $\mathrm{N}$ tended to be increased $(P=0.10)$ for the ESBM diets compared with SSBM (Table 7). Urinary urea $\mathrm{N}$ (UUN) excretion was increased $(P=0.01)$, and as a result, UUN excretion as a proportion of $\mathrm{N}$ intake tended to be higher $(P=0.08)$ for the ESBM diets ver- 
Table 6. Blood plasma AA concentration $(\mu M)$ in dairy cows fed diets containing solvent-extracted or extruded soybean meals $(\mathrm{SBM})$

\begin{tabular}{|c|c|c|c|c|c|}
\hline \multirow[b]{2}{*}{ Item } & \multicolumn{3}{|c|}{ Diet $^{1}$} & \multirow[b]{2}{*}{$\mathrm{SEM}^{2}$} & \multirow[b]{2}{*}{$P$-value } \\
\hline & SSBM & LTM & HTM & & \\
\hline \multicolumn{6}{|l|}{ EAA } \\
\hline Arg & 66.3 & 69.6 & 69.5 & 2.98 & 0.37 \\
\hline His & $39.9^{\mathrm{b}}$ & $43.3^{\mathrm{b}}$ & $50.0^{\mathrm{a}}$ & 2.62 & $<0.01$ \\
\hline Ile & 100 & 105 & 112 & 5.36 & 0.07 \\
\hline Leu & $115^{\mathrm{b}}$ & $121^{\mathrm{b}}$ & $133^{\mathrm{a}}$ & 7.34 & 0.02 \\
\hline Lys & 66.6 & 66.9 & 64.4 & 2.19 & 0.58 \\
\hline Met & $18.4^{\mathrm{b}}$ & $16.7^{\mathrm{a}}$ & $16.4^{\mathrm{a}}$ & 1.14 & 0.05 \\
\hline Phe & 39.3 & 39.5 & 40.5 & 1.45 & 0.66 \\
\hline Thr & 90.3 & 85.0 & 79.4 & 5.08 & 0.07 \\
\hline Trp & 67.5 & 66.6 & 67.4 & 2.67 & 0.97 \\
\hline Val & $190^{\mathrm{b}}$ & $196^{\mathrm{b}}$ & $215^{\mathrm{a}}$ & 12.2 & 0.03 \\
\hline \multicolumn{6}{|l|}{ NEAA } \\
\hline Ala & 197 & 202 & 208 & 9.33 & 0.55 \\
\hline Asn & 33.8 & 33.7 & 34.3 & 0.97 & 0.90 \\
\hline Asp & 6.30 & 6.15 & 7.19 & 0.75 & 0.32 \\
\hline Cit & 65.9 & 73.7 & 71.0 & 6.45 & 0.17 \\
\hline Cys & 0.22 & 0.30 & 0.27 & 0.08 & 0.84 \\
\hline Gln & 208 & 203 & 198 & 5.34 & 0.40 \\
\hline Glu & 44.3 & 45.1 & 44.8 & 2.18 & 0.81 \\
\hline Gly & 241 & 243 & 254 & 15.3 & 0.35 \\
\hline Orn & 36.7 & 37.7 & 38.4 & 1.67 & 0.59 \\
\hline Pro & $69.0^{\mathrm{b}}$ & $73.4^{\mathrm{ab}}$ & $79.8^{\mathrm{a}}$ & 3.05 & 0.02 \\
\hline Ser & 78.6 & 78.6 & 83.1 & 2.63 & 0.13 \\
\hline Tau & 30.4 & 31.8 & 35.4 & 2.26 & 0.06 \\
\hline Tyr & 40.8 & 40.6 & 40.6 & 2.26 & 0.99 \\
\hline $1-\mathrm{MH}^{4}$ & $4.99^{\mathrm{b}}$ & $4.87^{\mathrm{b}}$ & $7.88^{\mathrm{a}}$ & 0.58 & $<0.001$ \\
\hline $3-\mathrm{MH}^{4}$ & 3.39 & 3.50 & 3.08 & 0.38 & 0.10 \\
\hline Anserine & 0.03 & 0.09 & $\mathrm{ND}^{3}$ & 0.05 & 0.15 \\
\hline Carnosine & $10.3^{\mathrm{b}}$ & $12.0^{\mathrm{a}}$ & $12.7^{\mathrm{a}}$ & 0.68 & 0.02 \\
\hline EAA & 794 & 811 & 850 & 37.8 & 0.12 \\
\hline NEAA & 914 & 922 & 948 & 29.2 & 0.34 \\
\hline $\mathrm{EAA}+\mathrm{NEAA}$ & 1,708 & 1,733 & 1,798 & 60.9 & 0.14 \\
\hline
\end{tabular}

${ }_{\mathrm{a}, \mathrm{b}}$ Means with different letter superscripts differ at $P<0.05$.

${ }^{1} \mathrm{SSBM}=$ solvent-extracted $\mathrm{SBM} ; \mathrm{LTM}=\mathrm{SBM}$ extruded at $149^{\circ} \mathrm{C} ; \mathrm{HTM}=\mathrm{SBM}$ extruded at $171^{\circ} \mathrm{C}$.

${ }^{2}$ Largest SEM published in table; $\mathrm{n}=26$ ( $\mathrm{n}$ represents number of observations used in the statistical analysis). Data are presented as LSM.

${ }^{3}$ Not detected.

${ }^{4} 1$ - and 3-methylhistidine.

sus SSBM. Estimated total N losses with urine, feces, and milk, urine output, and urinary excretion of purine derivatives were not affected by diet.

Ruminal ammonia concentration was numerically increased $(P=0.15)$ for the ESBM diets compared with SSBM, whereas all other rumen fermentation parameters were not affected by diet (Table 8). Bacterial and archaeal order and genus compositions of whole ruminal contents are presented in Table 9. Fibrobacterales, Fibrobacter, and Barnesiella were increased $(P \leq 0.04)$ by HTM compared with SSBM and LTM. Rhodocyclales and Azospira tended to be increased $(P=0.08)$, and Alistipes was decreased $(P<0.01)$, respectively, by the ESBM diets versus SSBM. Dorea was increased $(P=$ 0.04) by HTM compared with LTM. The order or genus composition of methanogenic archaea was not affected by treatment.
The in situ $\mathrm{N}$ degradability, or disappearance, data for the $3 \mathrm{SBM}$ are shown in Figure 1 . The rate of $\mathrm{N}$ degradability was about 1.8 to 2.6 times greater $(P$ $\leq 0.002)$ for SSBM versus both LTM and HTM. The rate of $\mathrm{N}$ degradation was not different between the 2 extruded meals. Similarly, ED of $\mathrm{N}$ was greater $(P<$ 0.001) for SSBM versus ESBM and ED of LTM was also greater $(P<0.001)$ than that of HTM.

Data for the heat-stability test of Lys in SSBM are shown in Figure 2. Although not analyzed statistically $(\mathrm{n}=1)$, Lys concentration in SSBM protein appears to have started to markedly decrease with heating temperatures $>160^{\circ} \mathrm{C}$ for $1 \mathrm{~h}$ : an average of 6.61 for temperatures between 0 (unheated) and $140^{\circ} \mathrm{C}$ versus $6.50,6.37$, and $5.78 \%$ of the total analyzed AA for 160 , 180 , and $200^{\circ} \mathrm{C}$, respectively. 
Table 7. Milk N secretion, urinary and fecal N excretion, and urinary purine-derivative (PD) excretion in dairy cows fed diets containing solvent-extracted or extruded soybean meals (SBM)

\begin{tabular}{lccccc}
\hline & \multicolumn{3}{c}{ Diet $^{1}$} & & \\
\cline { 2 - 4 } & SSBM & LTM & HTM & SEM $^{2}$ & P-value \\
\hline Item & $688^{\mathrm{b}}$ & $722^{\mathrm{a}}$ & $718^{\mathrm{a}}$ & 29.4 & 0.05 \\
$\mathrm{~N}$ intake, g/d & & & & & \\
N secretion and excretion, g/d & 174 & 184 & 183 & 7.2 & 0.10 \\
Milk TPN $^{3}$ & 153 & 176 & 175 & 14.4 & 0.26 \\
Urinary N & $93^{\mathrm{b}}$ & $117^{\mathrm{a}}$ & $116^{\mathrm{a}}$ & 7.9 & 0.01 \\
Urinary urea N (UUN), g/d & 61.8 & 69.5 & 67.3 & 4.68 & 0.51 \\
UUN † total urinary N, \% & 245 & 246 & 235 & 11.7 & 0.66 \\
Fecal N & 398 & 423 & 413 & 21.1 & 0.48 \\
Total excreta N & 572 & 609 & 598 & 24.6 & 0.24 \\
Total N in excreta and milk & & & & & \\
As proportion of N intake \% & 25.5 & 25.5 & 25.6 & 0.84 & 0.97 \\
Milk TPN & 21.9 & 23.1 & 22.9 & 1.72 & 0.88 \\
Urine N & 13.5 & 15.8 & 15.6 & 0.78 & 0.08 \\
UUN & 35.8 & 34.4 & 33.5 & 1.22 & 0.29 \\
Fecal N & 83.5 & 84.2 & 83.9 & 2.11 & 0.96 \\
Total N in excreta and milk & 19.7 & 21.6 & 21.5 & 1.72 & 0.48 \\
Urine output, kg/d & & & & & \\
Urinary PD excretion, mmol/d & 548 & 514 & 529 & 37.8 & 0.71 \\
Allantoin & 63.8 & 60.2 & 62.4 & 6.17 & 0.78 \\
Uric acid & 611 & 574 & 591 & 42.1 & 0.71 \\
Total PD & & & & \\
\hline
\end{tabular}

${ }^{\mathrm{a}, \mathrm{b}}$ Means with different letter superscripts differ at $P<0.05$.

${ }^{1} \mathrm{SSBM}=$ solvent-extracted $\mathrm{SBM} ; \mathrm{LTM}=\mathrm{SBM}$ extruded at $149^{\circ} \mathrm{C} ; \mathrm{HTM}=\mathrm{SBM}$ extruded at $171^{\circ} \mathrm{C}$.

${ }^{2}$ Largest SEM published in table; $\mathrm{n}=26$ ( $\mathrm{n}$ represents number of observations used in the statistical analysis). Data are presented as LSM.

${ }^{3}$ Milk true protein N (milk true protein $\div 6.38$ ).

Table 8. Rumen fermentation variables in dairy cows fed diets containing solvent-extracted or extruded soybean meals $(\mathrm{SBM})$

\begin{tabular}{|c|c|c|c|c|c|}
\hline \multirow[b]{2}{*}{ Item } & \multicolumn{3}{|c|}{ Diet $^{1}$} & \multirow[b]{2}{*}{$\mathrm{SEM}^{2}$} & \multirow[b]{2}{*}{$P$-value } \\
\hline & SSBM & LTM & HTM & & \\
\hline $\mathrm{pH}$ & 5.93 & 6.04 & 6.02 & 0.106 & 0.55 \\
\hline Ammonia, $\mathrm{m} M$ & 2.40 & 2.76 & 2.82 & 0.180 & 0.15 \\
\hline \multicolumn{6}{|l|}{ VFA, mM } \\
\hline Total & 137.2 & 138.9 & 140.3 & 5.29 & 0.86 \\
\hline Acetate & 83.5 & 85.8 & 87.0 & 2.63 & 0.55 \\
\hline Propionate & 28.7 & 27.6 & 29.2 & 2.11 & 0.85 \\
\hline Butyrate & 19.2 & 19.3 & 17.8 & 1.35 & 0.46 \\
\hline Isobutyrate & 1.01 & 0.98 & 0.98 & 0.058 & 0.82 \\
\hline Valerate & 2.74 & 2.80 & 2.69 & 0.128 & 0.71 \\
\hline Isovalerate & 2.21 & 2.09 & 2.24 & 0.212 & 0.77 \\
\hline \multicolumn{6}{|l|}{ As $\%$ of total } \\
\hline Acetate & 61.0 & 61.7 & 61.7 & 0.84 & 0.34 \\
\hline Propionate & 20.6 & 19.7 & 20.5 & 1.00 & 0.84 \\
\hline Butyrate & 13.9 & 13.8 & 12.5 & 0.77 & 0.32 \\
\hline Isobutyrate & 0.76 & 0.72 & 0.74 & 0.038 & 0.74 \\
\hline Valerate & 2.01 & 2.02 & 1.93 & 0.047 & 0.35 \\
\hline Isovalerate & 1.69 & 1.55 & 1.72 & 0.152 & 0.73 \\
\hline Acetate:propionate & 3.05 & 3.18 & 3.06 & 0.181 & 0.86 \\
\hline
\end{tabular}

${ }^{1} \mathrm{SSBM}=$ solvent-extracted $\mathrm{SBM} ; \mathrm{LTM}=\mathrm{SBM}$ extruded at $149^{\circ} \mathrm{C} ; \mathrm{HTM}=\mathrm{SBM}$ extruded at $171^{\circ} \mathrm{C}$.

${ }^{2}$ Largest SEM published in table. Rumen $\mathrm{pH}$, ammonia, and VFA data, $\mathrm{n}=17$ (n represents number of observations used in the statistical analysis). Data are presented as LSM. 
Table 9. Bacterial and archaeal order and genus composition (as $\%$ of total isolates ${ }^{1}$ ) in whole ruminal contents of dairy cows fed diets containing solvent-extracted or extruded soybean meals (SBM)

\begin{tabular}{|c|c|c|c|c|c|}
\hline \multirow[b]{2}{*}{ Item } & \multicolumn{3}{|c|}{ Diet $^{2}$} & \multirow[b]{2}{*}{$\mathrm{SEM}^{3}$} & \multirow[b]{2}{*}{$P$-value } \\
\hline & SSBM & LTM & HTM & & \\
\hline \multicolumn{6}{|l|}{ Bacteria order } \\
\hline Clostridiales & 55.1 & 55.5 & 55.1 & 1.56 & 0.50 \\
\hline Bacteroidales & 26.5 & 25.9 & 24.1 & 1.41 & 0.49 \\
\hline Bifidobacteriales & 3.49 & 3.49 & 2.87 & 1.519 & 0.50 \\
\hline Fibrobacterales & $2.01^{\mathrm{b}}$ & $2.33^{\mathrm{b}}$ & $3.48^{\mathrm{a}}$ & 0.377 & 0.04 \\
\hline Erysipelotrichales & 1.96 & 2.34 & 2.47 & 0.360 & 0.22 \\
\hline Spirochaetales & 1.51 & 1.73 & 1.76 & 0.292 & 0.63 \\
\hline Lactobacillales & 1.60 & 1.51 & 1.36 & 0.157 & 0.46 \\
\hline Rhodocyclales & 1.04 & 1.77 & 1.68 & 0.218 & 0.08 \\
\hline Chromatiales & 1.30 & 1.10 & 1.19 & 0.179 & 0.76 \\
\hline Micrococcales & 1.07 & 1.12 & 1.29 & 0.224 & 0.52 \\
\hline Mycoplasmatales & 1.04 & 1.01 & 0.69 & 0.216 & 0.45 \\
\hline \multicolumn{6}{|l|}{ Bacteria genus } \\
\hline Prevotella & 16.9 & 16.9 & 14.6 & 1.45 & 0.43 \\
\hline Ruminococcus & 7.96 & 6.53 & 6.89 & 0.94 & 0.48 \\
\hline Clostridium & 6.07 & 6.04 & 5.66 & 0.28 & 0.55 \\
\hline Butyrivibrio & 4.98 & 5.28 & 5.99 & 0.39 & 0.26 \\
\hline Acetitomaculum & 5.11 & 5.03 & 5.42 & 0.34 & 0.54 \\
\hline Coprococcus & 4.44 & 4.48 & 4.98 & 0.85 & 0.56 \\
\hline Blautia & 4.65 & 4.71 & 4.44 & 0.46 & 0.89 \\
\hline Barnesiella & $4.04^{\mathrm{b}}$ & $3.94^{\mathrm{b}}$ & $4.44^{\mathrm{a}}$ & 0.35 & $<0.01$ \\
\hline Pseudobutyrivibrio & 3.36 & 3.48 & 3.74 & 0.36 & 0.69 \\
\hline Saccharofermentans & 3.02 & 3.40 & 3.11 & 0.22 & 0.24 \\
\hline Bifidobacterium & 3.49 & 3.49 & 2.87 & 1.52 & 0.50 \\
\hline Dorea & 2.85 & 2.49 & 3.58 & 0.26 & $0.09^{4}$ \\
\hline Succiniclasticum & 2.80 & 2.71 & 2.34 & 0.32 & 0.62 \\
\hline Fibrobacter & $2.01^{\mathrm{b}}$ & $2.33^{\mathrm{b}}$ & $3.48^{\mathrm{a}}$ & 0.38 & 0.04 \\
\hline Fecalibacterium & 1.66 & 2.21 & 1.80 & 0.24 & 0.13 \\
\hline Treponema & 1.49 & 1.71 & 1.74 & 0.29 & 0.61 \\
\hline Alistipes & $1.98^{\mathrm{a}}$ & $1.34^{\mathrm{b}}$ & $0.95^{\mathrm{b}}$ & 0.22 & $<0.01$ \\
\hline Catenibacterium & 1.35 & 1.66 & 1.61 & 0.19 & 0.43 \\
\hline Azospira & 1.04 & 1.77 & 1.68 & 0.22 & 0.08 \\
\hline Streptococcus & 1.56 & 1.47 & 1.32 & 0.16 & 0.47 \\
\hline Bacteroides & 1.30 & 1.19 & 1.41 & 0.19 & 0.19 \\
\hline Flavonifractor & 1.06 & 1.28 & 1.39 & 0.20 & 0.45 \\
\hline Xylanibacter & 1.24 & 1.24 & 1.17 & 0.12 & 0.83 \\
\hline Roseburia & 1.24 & 1.02 & 1.48 & 0.21 & 0.34 \\
\hline Thioalkalibacter & 1.29 & 1.09 & 1.19 & 0.18 & 0.76 \\
\hline Dermatophilus & 1.07 & 1.12 & 1.29 & 0.22 & 0.52 \\
\hline Sarcina & 1.02 & 1.16 & 0.78 & 0.18 & 0.40 \\
\hline Mycoplasma & 1.04 & 1.01 & 0.69 & 0.22 & 0.45 \\
\hline \multicolumn{6}{|l|}{ Archaea order } \\
\hline Methanobacteriales & 99.9 & 99.9 & 99.9 & 0.04 & 0.80 \\
\hline Methanomicrobiales & 0.05 & 0.05 & 0.04 & 0.03 & 0.92 \\
\hline \multicolumn{6}{|l|}{ Archaea genus } \\
\hline Methanobrevibacter & 91.2 & 90.6 & 90.3 & 0.72 & 0.68 \\
\hline Methanosphaera & 8.74 & 9.25 & 9.65 & 0.71 & 0.67 \\
\hline Methanomicrobium & 0.05 & 0.05 & 0.04 & 0.03 & 0.92 \\
\hline
\end{tabular}

${ }^{\mathrm{a}, \mathrm{b}}$ Means with different letter superscripts differ at $P<0.05$.

${ }^{1}$ The percentage represents the percentage of the total sequences analyzed within the sample.

${ }^{2} \mathrm{SSBM}=$ solvent-extracted $\mathrm{SBM} ; \mathrm{LTM}=\mathrm{SBM}$ extruded at $149^{\circ} \mathrm{C} ; \mathrm{HTM}=\mathrm{SBM}$ extruded at $171^{\circ} \mathrm{C}$.

${ }^{3}$ Largest SEM published in table; $\mathrm{n}=17$ ( $\mathrm{n}$ represents number of observations used in the statistical analysis). Data are presented as LSM.

${ }^{4} \mathrm{HTM}$ versus $\operatorname{LTM}(P=0.04)$.

\section{DISCUSSION}

As a result of exposure to a higher temperature during the extrusion process (known to reduce rumen degradability of CP; Solanas et al., 2008), the HTM had the highest RUP concentration followed by LTM and SSBM. In a pilot study leading to the current experiment (Isenberg et al., 2012), we observed a linear increase $\left(\mathrm{R}^{2}=0.99\right)$ in RUP content, estimated from in situ protein degradability data, of ESBM with extru- 


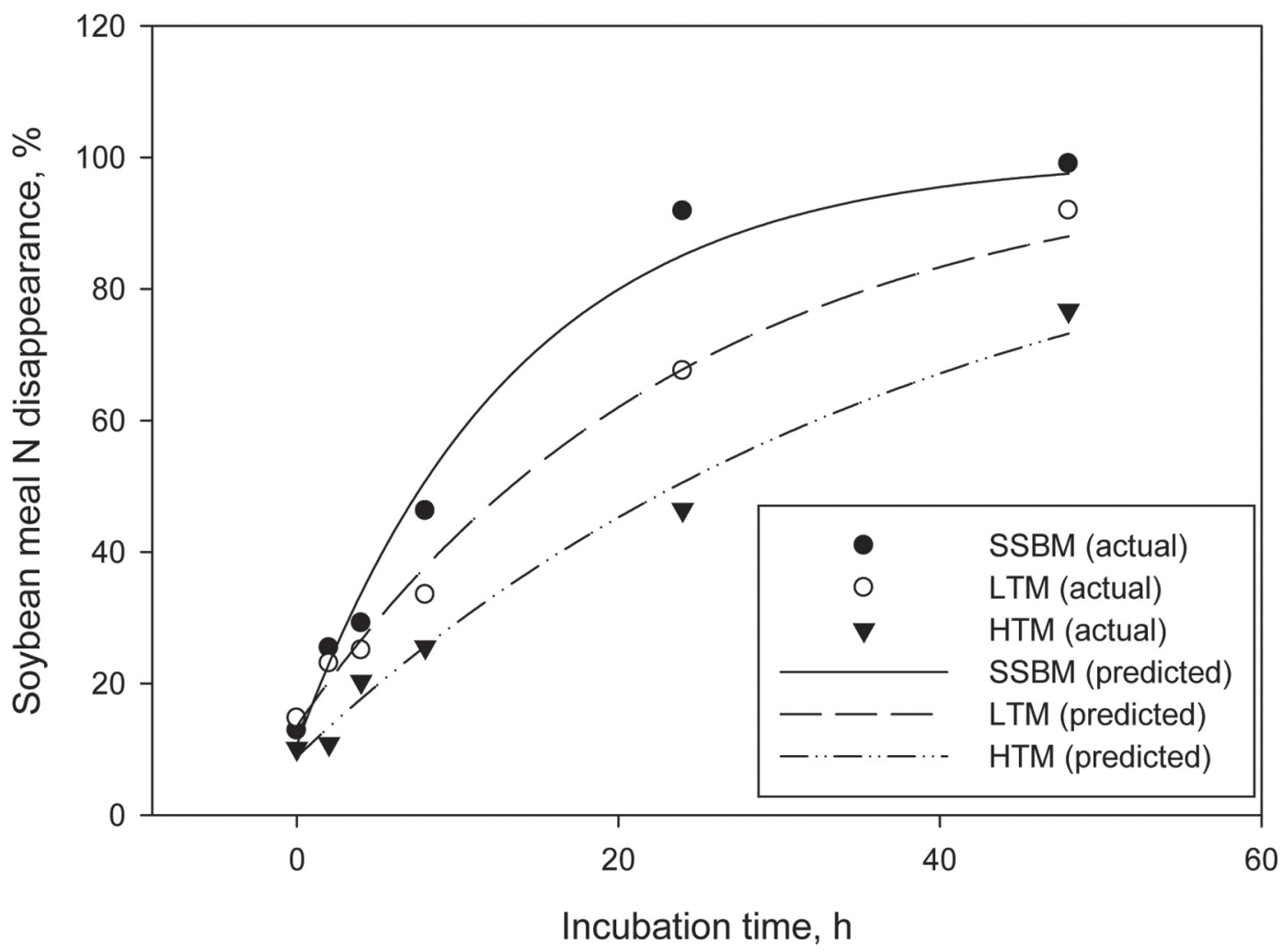

Figure 1. In situ disappearance of nitrogen from the soybean meals (SBM) used in the experiment. SSBM = solvent-extracted SBM; LTM $=\mathrm{SBM}$ extruded at $149^{\circ} \mathrm{C} ; \mathrm{HTM}=\mathrm{SBM}$ extruded at $171^{\circ} \mathrm{C}$. Rate of disappearance $(\% / \mathrm{h}): 6.8^{\mathrm{a}} \pm 0.83,3.7^{\mathrm{b}} \pm 0.76$, and $2.6^{\mathrm{b}} \pm 0.74(\mathrm{SSBM}$, LTM, and HTM, respectively); Effective degradability (\%; estimated at $6 \% / \mathrm{h}$ rate of passage): $60.4^{\mathrm{a}} \pm 1.41,48.2^{\mathrm{b}} \pm 1.64$, and $36.2^{\mathrm{c}} \pm 1.44$, respectively. Means with different letters $(\mathrm{a}-\mathrm{c})$ differ at $P \leq 0.009$.

sion temperatures of 149,160 , and $171^{\circ} \mathrm{C}$. It is worth noticing that in that study, meal output was decreased by about $13 \%$ by increasing the extrusion temperature from 149 to $171^{\circ} \mathrm{C}$.

The observed lower concentration of some EAA (e.g., Arg, His, and Phe) in the ESBM diets compared with SSBM, and the lower Lys concentration with the higher extrusion temperature (i.e., HTM), is in agreement with several other studies (Sahlu et al., 1984; Broderick, 1986) on heat-treated SBM. A similar decrease in Lys concentration of SBM with increasing the heating temperature above $160^{\circ} \mathrm{C}$ was also observed in the pilot study reported in Figure 2. These effects have been attributed to formation of Maillard products and cross links among AA (Björck and Asp, 1983; Csapó et al., 2008).

The effect of the ESBM on DMI and milk production in the current experiment was remarkable. The diets were not deficient in $\mathrm{NE}_{\mathrm{L}}$ and supplied $\mathrm{MP}$ in excess of NRC (2001) requirements. The estimated balance of key EAA was also similar between SSBM and the ESBM diets. Based on the current NRC (2001) requirements, the increased milk yield with ESBM cannot be attributed to increased RUP or $\mathrm{NE}_{\mathrm{L}}$ (due to higher fat content) concentration or supply. Thus, it appears that the increased milk yield with LTM and HTM was primarily due to the increased DMI with these diets compared with SSBM. This is supported by the similar feed efficiency among the diets (although some numerical increase appeared to occur with the ESBM diets).

Earlier studies with heat-treated SBM reported increased milk yield and feed efficiency in high- (but not low-) producing dairy cows (Sahlu et al., 1984). A series of experiments with expeller SBM (reaching maximum processing temperature of $163^{\circ} \mathrm{C}$ ) showed variable responses in milk yield compared with SSBM, in spite of much greater concentration of RUP than SSBM (Broderick, 1986; Broderick et al., 1990). Those experiments suggested that protein from expeller SBM can replace greater amounts of SSBM and maintain the same level of production. Socha (1991) summarized 9 experiments with heat-treated SBM conducted between 1979 and 1990 and reported increased DMI in 3 and increased milk yield in 8 of the experiments. Milk fat and protein concentrations appeared to be decreased in 6 experiments. Overall, milk yield was increased by $1.8 \mathrm{~kg} / \mathrm{d}$ at 


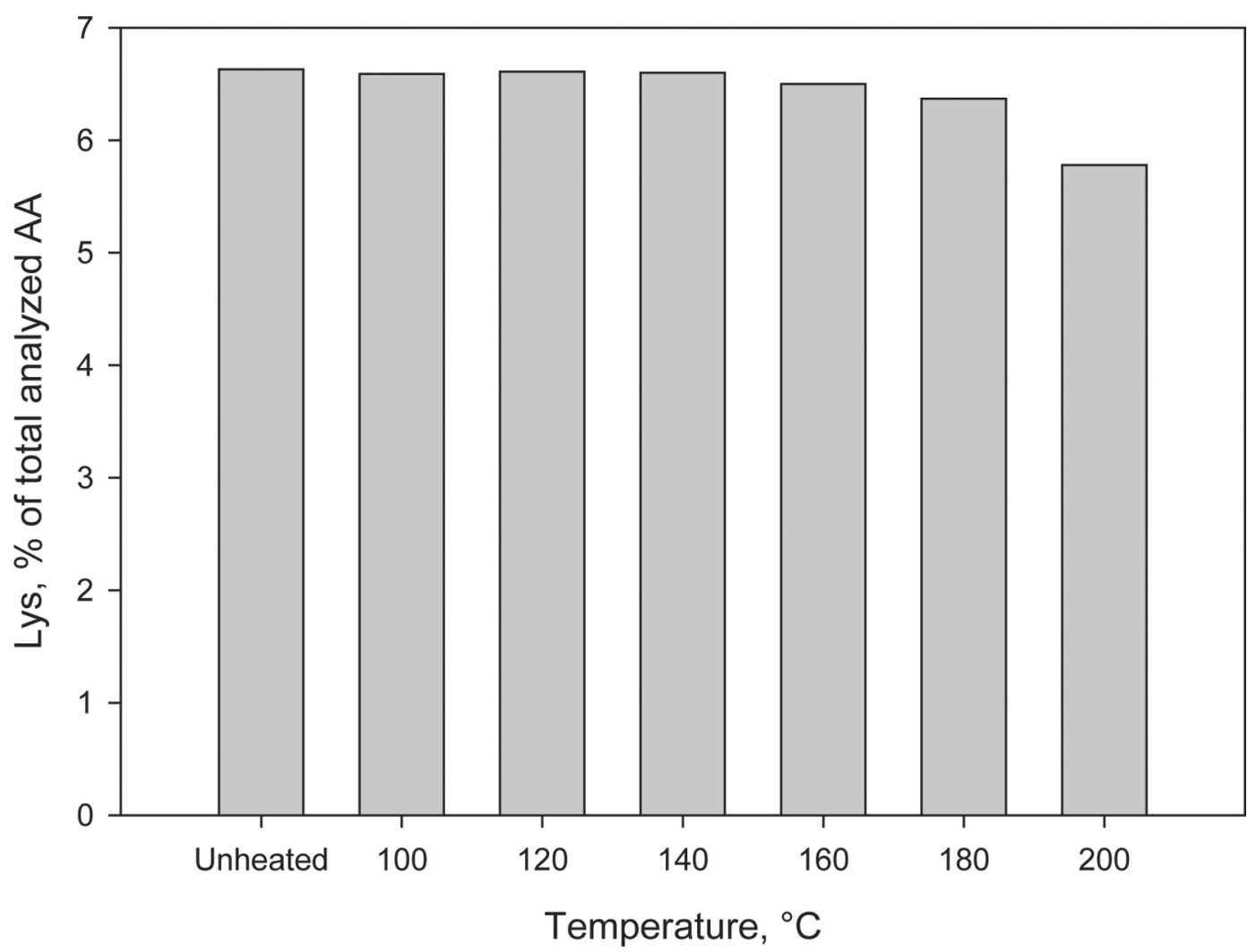

Figure 2. Concentration of Lys in solvent-extracted soybean meal heated for 60 min at different temperatures (a single sample was analyzed at each temperature; $\mathrm{SD}=0.28$ ).

similar or slightly lower $(-0.1 \mathrm{~kg} / \mathrm{d})$ DMI. Similar to data from the current experiment, Flis and Wattiaux (2005) reported increased DMI and milk production with expeller SBM supplemented at about $10 \%$ over NRC (2001) requirements for RUP. In a more recent study by Broderick et al. (2009), expeller SBM had no effect on milk yield (a $0.8 \mathrm{~kg} / \mathrm{d}$ numerical increase occurred), but feed efficiency, milk fat concentration, and $3.5 \%$ FCM milk yield were increased compared with the control, SSBM, diet. Others, however, reported no or variable effects of heat-treated SBM on feed intake or lactational performance of dairy cows (Ipharraguerre et al., 2005; Awawdeh et al., 2007).

The general trend in milk FA composition observed in the current experiment was for decreased concentration of FA with chain length up to $\mathrm{C} 17$ and increased concentration of long-chain, C18 FA, with ESBM. This resulted in increased concentrations of CLA, total trans FA, MUFA, and PUFA, but decreased total SFA. It is established that long-chain FA in milk fat are predominantly derived from dietary sources (Palmquist and Jenkins, 1980), and therefore, the results with ESBM in the current experiment are not surprising. A similar increase in milk C18 FA from cows fed heat-treated soybean meal, whole-soybeans, or soybean oil is commonly reported in the literature (Socha, 1991; Sauer et al., 1998; AlZahal et al., 2008; Chen et al., 2008).

Plasma concentration of several key EAA, such as His, Leu, and Val, increased as a result of feeding ESBM, particularly HTM, in the current experiment. Concentration of Met, however, considered first or second (along with Lys) limiting AA in typical North American dairy diets (NRC, 2001), was decreased by ESBM. In the experiments of Broderick (1986), plasma concentrations of EAA were similar between diets containing expeller SBM versus SSBM. Similar to our current data, however, Met concentration decreased in the experiment with the highest inclusion rate of expeller SBM. Awawdeh et al. (2007) also did not report differences in plasma AA concentrations between cows fed diets with SSBM or expeller SBM. In that experiment, the AA composition of SSBM and expeller SBM was also not different and digestibility of RUP from expeller SBM, tested in chicken, was not different from that of SSBM. Based on the hypothesis that EAA will not accumulate in blood plasma unless supplied in excess of requirement (Almquist, 1954; Broderick et al., 1974) and the lower plasma concentration of Met in cows fed 
ESBM (which also had higher milk yield, compared with the control), it could be concluded that Met was perhaps the first limiting AA in the current experiment. This is in agreement with the data by Broderick (1986), who also found decreased plasma Met and total sulfur AA with expeller SBM in one of their experiments. The greater concentrations of His, Leu, and Val with ESBM in the current experiment can be explained with increased supply of these AA with RUP, compared with SSBM. Carnosine is a dipeptide containing $\beta$-Ala and His and muscle carnosine is considered an endogenous source of His in ruminants or monogastric animals (see discussion in Giallongo et al., 2015). Its increased concentration with the ESBM diets is in agreement with the increased plasma His concentrations. The increase in plasma 1-MH with HTM was interesting and consistent among experimental animals $(\mathrm{SE}=0.57 \mu M)$. Plasma 1-MH may result from the metabolism of the dipeptide anserine contained in meat and fish, and its excretion in urine was suggested as a marker for meat intake in animals or humans (Myint et al., 2000). It is not clear why HTM triggered such a large response in plasma 1-HM concentration, particularly with the lack of increase in 3-MH, considered a marker for muscle catabolism. In fact, a trend was observed for decreased 3 -MH with HTM versus LTM $(P=0.12)$ or the control $(P=0.04)$.

Broderick (1986) suggested that heating of SBM could result in decreased Lys availability. In one of his experiments with expeller SBM (in which the inclusion rate was the highest; $22 \%$ on DM basis), replacing SSBM with expeller SBM resulted in decreased plasma Lys concentration and the appearance of an unidentified postlysine peak (presumed to be derived from Lys during the expeller processing). In the pilot study conducted along with the current experiment, concentration of Lys in SSBM heated at temperatures of up to $140^{\circ} \mathrm{C}$ (which was the processing temperature reached for LTM) was similar to unheated SSBM. On the other hand, Lys concentration declined by $4 \%$ at $180^{\circ} \mathrm{C}$ (close to the processing temperature of HTM) and then continued to decline to $87 \%$ of the unheated SSBM at $200^{\circ} \mathrm{C}$. Except for hydroxyproline, which decreased by $19 \%$, the concentration of all other AA was unaltered by heating at $200^{\circ} \mathrm{C}$. A much sharper $16 \%$ decline in Lys concentration of SSBM heated to $160^{\circ} \mathrm{C}$ for $30 \mathrm{~min}$ was reported by Hsu and Satter (1995). These authors, however, also observed a slight (5\%) increase in plasma Lys concentration in heifers with increasing heating temperature (up to $153^{\circ} \mathrm{C}$ ), which is indicative of increased rumen stability and postruminal availability of Lys from heated SSBM, in spite of its decreased concentration. Ipharraguerre et al. (2005) also reported lower Lys concentration in expeller SBM compared with SSBM, but greater duodenal flow of EAA, including Lys, with the nonmicrobial fraction of $\mathrm{N}$ when expeller SBM was included in the diet of lactating dairy cows.

The ESBM diets contained urea (to achieve a similar N concentration to the SSBM diet) and total N intake was greater than the SSBM diet, which explains the increased urinary urea-N excretion with LTM and HTM observed in the current experiment. The urinary urea excretion data are in agreement with the increased MUN and the trends for increased rumen ammonia and PUN concentrations with the ESBM diets. These results are not surprising as the effects of increased total protein (or RDP) intake on rumen ammonia, urinary $\mathrm{N}$ excretion, and MUN are well documented (Olmos Colmenero and Broderick, 2006). The lack of effect of ESBM on fecal $\mathrm{N}$ excretion is in agreement with the similar total-tract $\mathrm{N}$ digestibility between SSBM and the ESBM diets. The ESBM diets did contain higher concentrations of total fat, originating from the higher fat content of the ESBM vs. SSBM, but this did not appear to negatively affect ruminal fermentation or totaltract fiber digestibility. Although milk fat concentration was slightly (numerically) lower for the ESBM diets, rumen VFA concentrations and acetate:propionate ratio were similar among the diets and trans-10, cis-12 CLA, implicated in milk fat depression (Baumgard et al., 2000), was not detected in milk fat.

Fibrobacterales were increased by the HTM diet (and was numerically higher for LTM), compared with SSBM, in the current experiment. Fibrobacter spp. are predominant fibrolytic bacteria in the rumen (Stewart and Flint, 1989), and it is possible that their proportional increase with the ESBM diets was due to the urea inclusion and the numerically higher rumen ammonia concentration with these diets; the preference for ammonia $\mathrm{N}$ of ruminal fibrolytic bacteria has been documented (Russell et al., 1992). Ammonia concentration in ruminal fluid was relatively low in this experiment compared with average values reported in a meta-analysis (Broderick et al., 2010) or our own data with low-protein diets (Lee et al., 2015). Thus, it is plausible that rumen ammonia may have limited certain fibrolytic species in the current experiment, which might have been partially alleviated by the addition of urea to the ESBM diets. The effect of HTM on other bacteria, such as Barnesiella and the saccharolytic Dorea, is difficult to explain. Rumen archaea were not affected by treatment in the current experiment, although the effect of fat, specifically unsaturated FA, on rumen methanogens and enteric methane emission is often reported in the literature (Hristov et al., 2013b). 


\section{CONCLUSIONS}

This experiment used SBM extruded at 2 extruder temperatures that were compared with SSBM as part of TMR for lactating dairy cows. Protein from ESBM had slower degradation rate and lower rumen degradability compared with SSBM. The experimental data conclusively showed that ESBM, perhaps being more palatable to the cows, increased DMI and consequently milk yield without affecting milk composition or feed efficiency. The ESBM diets, likely as a result of inclusion of NPN as urea, numerically increased rumen ammonia concentration, and increased urinary urea $\mathrm{N}$ excretion and MUN concentration. The ESBM diets tended to decrease most milk FA with chain length up to C17 and increased C18 FA in milk. Overall, data from this crossover experiment suggest that substituting SSBM with ESBM in the diet will have a positive effect on feed intake and milk yield in dairy cows.

\section{ACKNOWLEDGMENTS}

This project was partially supported by funds from the Pennsylvania Soybean Board (Agreement R2012008). The authors thank Fabin Bros. Farms (Indiana, PA) for providing the extruded soybean meal for the experiment, B. Corl (Department of Dairy Science, Virginia Polytechnic Institute and State University) for the milk FA analysis, and the staff of the Department of Animal Science Dairy Center (The Pennsylvania State University) for their conscientious care of the experimental cows.

\section{REFERENCES}

Almquist, H. J. 1954. Utilization of amino acids by chicks. Arch. Biochem. Biophys. 52:197-202.

AlZahal, O., N. E. Odongo, T. Mutsvangwa, M. M. Or-Rashid, T. F. Duffield, R. Bagg, P. Dick, G. Vessie, and B. W. McBride. 2008. Effects of monensin and dietary soybean oil on milk fat percentage and milk fatty acid profile in lactating dairy cows. J. Dairy Sci. 91:1166-1174.

AOAC International. 2006. Official Methods of Analysis. 18th ed. AOAC Int., Gaithersburg, MD

Awawdeh, M. S., E. C. Titgemeyer, J. S. Drouillard, R. S. Beyer, and J. E. Shirley. 2007. Ruminal degradability and lysine bioavailability of soybean meals and effects on performance of dairy cows. J. Dairy Sci. 90:4740-4753.

Bach Knudsen, K. E. 1997. Carbohydrate and lignin contents of plant materials used in animal feeding. Anim. Feed Sci. Technol. 67:319-338.

Baumgard, L. H., B. A. Corl, D. A. Dwyer, A. Sæbø, and D. E. Bauman. 2000. Identification of the conjugated linoleic acid isomer that inhibits milk fat synthesis. Am. J. Physiol. Regul. Integr. Comp. Physiol. 278:R179-R184.

Björck, I., and N.-G. Asp. 1983. The effects of extrusion cooking on nutritional value - A literature review. J. Food Eng. 2:281-308.

Broderick, G. A. 1986. Relative value of solvent and expeller soybean meal for lactating dairy cows. J. Dairy Sci. 69:2948-2958.
Broderick, G. A., P. Huhtanen, S. Ahvenjärvi, S. M. Reynal, and K. J. Shingfield. 2010. Quantifying ruminal nitrogen metabolism using the omasal sampling technique in cattle-A meta-analysis. J. Dairy Sci. 93:3216-3230.

Broderick, G. A., D. B. Ricker, and S. Driver. 1990. Expeller soybean meal and corn by-products versus solvent soybean meal for lactating dairy cows fed alfalfa silage as sole forage. J. Dairy Sci. 73:453-462.

Broderick, G. A., L. D. Satter, and A. E. Harper. 1974. Use of plasma amino acid concentration to identify limiting amino acids for milk production. J. Dairy Sci. 57:1015-1023.

Broderick, G. A., M. J. Stevenson, and R. A. Patton. 2009. Effect of dietary protein concentration and degradability on response to rumen-protected methionine in lactating dairy cows. J. Dairy Sci. 92:2719-2728.

Chen, P., P. Ji, and S. L. Li. 2008. Effects of feeding extruded soybean, ground canola seed and whole cottonseed on ruminal fermentation, performance and milk fatty acid profile in early lactation dairy cows. Asian-australas. J. Anim. Sci. 21:204-213.

Csapó, J., E. Varga-Visi, K. Lóki, C. Albert, and S. Salamon. 2008 The influence of extrusion on loss and racemization of amino acids. Amino Acids 34:287-292.

CVAS (Cumberland Valley Analytical Services). 2014. Resources-Lab Procedures. Accessed Mar. 7, 2015. http://www.foragelab.com/ Resources/Lab-Procedures/.

Deyl, Z., J. Hyanek, and M. Horakova. 1986. Profiling of amino acids in body fluids and tissues by means of liquid chromatography. J. Chromatogr. 379:177-250.

Dhiman, T. R., C. Cadorniga, and L. D. Satter. 1993. Protein and energy supplementation of high alfalfa silage diets during early lactation. J. Dairy Sci. 76:1945-1959.

Fekkes, D. 1996. State-of-the-art of high-performance liquid chromatographic analysis of amino acids in physiological samples. J. Chromatogr. B Biomed. Appl. 682:3-22.

Flis, S. A., and M. A. Wattiaux. 2005. Effects of parity and supply of rumen-degraded and undegraded protein on production and nitrogen balance in Holsteins. J. Dairy Sci. 88:2096-2106.

Giallongo, F., A. N. Hristov, J. Oh, T. Frederick, H. Weeks, J. Werner, H. Lapierre, R. A. Patton, A. Gehman, and C. Parys. 2015. Effects of slow-release urea and rumen-protected methionine and histidine on performance of dairy cows. J. Dairy Sci. 98:3292-3308.

Hristov, A. N., C. Lee, T. Cassidy, K. Heyler, J. A. Tekippe, G. A. Varga, B. Corl, and R. C. Brandt. 2013a. Effect of Origanum vulgare $\mathrm{L}$. leaves on rumen fermentation, production, and milk fatty acid composition in lactating dairy cows. J. Dairy Sci. 96:1189-1202.

Hristov, A. N., C. Lee, T. Cassidy, M. Long, B. Corl, and R. Forster. 2011. Effects of lauric and myristic acids on ruminal fermentation, production, and milk fatty acid composition in lactating dairy cows. J. Dairy Sci. 94:382-395.

Hristov, A. N., J. Oh, J. Firkins, J. Dijkstra, E. Kebreab, G. Waghorn, H. P. S. Makkar, A. T. Adesogan, W. Yang, C. Lee, P. J. Gerber, B. Henderson, and J. M. Tricarico. 2013b. Mitigation of methane and nitrous oxide emissions from animal operations: I. A review of enteric methane mitigation options. J. Anim. Sci. 91:5045-5069.

Hristov, A. N., G. Varga, T. Cassidy, M. Long, K. Heyler, S. K. R. Karnati, B. Corl, C. J. Hovde, and I. Yoon. 2010. Effect of Saccharomyces cerevisiae fermentation product on ruminal fermentation and nutrient utilization in dairy cows. J. Dairy Sci. 93:682-692.

Hsu, J. T., and L. D. Satter. 1995. Procedures for measuring the quality of heat-treated soybeans. J. Dairy Sci. 78:1353-1361.

Ipharraguerre, I. R., J. H. Clark, and D. E. Freeman. 2005. Rumen fermentation and intestinal supply of nutrients in dairy cows fed rumen-protected soy products. J. Dairy Sci. 88:2879-2892.

Isenberg, B. J., A. N. Hristov, D. M. Kniffen, C. Lee, K. S. Heyler, T. W. Cassidy, and R. A. Fabin. 2012. Effect of temperature during drying and mechanical extrusion on soybean meal protein in situ degradability and in vitro digestibility. J. Dairy Sci. 95(Suppl. 2):216.

Krishnamoorthy, U., C. J. Sniffen, M. D. Stern, and P. J. Van Soest. 1983. Evaluation of a mathematical model of rumen digestion and an in vitro simulation of rumen proteolysis to estimate the 
rumen-undegraded nitrogen content of feedstuffs. Br. J. Nutr. 50:555-568.

Lee, C., F. Giallongo, A. N. Hristov, H. Lapierre, T. W. Cassidy, K. S. Heyler, G. A. Varga, and C. Parys. 2015. Effect of dietary protein level and rumen-protected amino acid supplementation on amino acid utilization for milk protein in lactating dairy cows. J. Dairy Sci. 98:1885-1902.

Lee, C., A. N. Hristov, T. W. Cassidy, K. S. Heyler, H. Lapierre, G. A. Varga, M. J. de Veth, R. A. Patton, and C. Parys. 2012. Rumen protected lysine, methionine, and histidine increase milk protein yield in dairy cows fed a metabolizable protein-deficient diet. J. Dairy Sci. 95:6042-6056.

Myint, T., G. E. Fraser, K. D. Lindsted, S. F. Knutsen, R. W. Hubbard, and H. W. Bennett. 2000. Urinary 1-methylhistidine is a marker of meat consumption in black and in white California seventh-day Adventists. Am. J. Epidemiol. 152:752-755.

NRC. 2001. Nutrient Requirements of Dairy Cattle. 7th rev. ed. Natl. Acad. Sci., Washington, DC.

Olmos Colmenero, J. J., and G. A. Broderick. 2006. Effect of dietary crude protein concentration on milk production and nitrogen utilization in lactating dairy cows. J. Dairy Sci. 89:1704-1712.

Ørskov, E. R., and I. McDonald. 1979. The estimation of protein degradability in the rumen from incubation measurements weighted according to rate of passage. J. Agric. Sci. (Camb.) 92:499-503.

Palmquist, D. L., and T. C. Jenkins. 1980. Fat in lactation rations . J. Dairy Sci. 63:1-14. (Review).

Patton, R. A., A. N. Hristov, and H. Lapierre. 2014. Protein feeding and balancing for amino acid in lactating dairy cattle. Pages 599-621 in Veterinary Clinics of North America. R. J. Van Saun and R. A. Smith, ed. Elsevier, Philadelphia, PA.
Russell, J. B., J. D. O'Connor, D. G. Fox, P. J. Van Soest, and C. J. Sniffen. 1992. A net carbohydrate and protein system for evaluating cattle diets: I. Ruminal fermentation. J. Anim. Sci. 70:35513561.

Sahlu, T., D. J. Schingoethe, and A. K. Clark. 1984. Lactational and chemical evaluation of soybean meals heat-treated by two methods. J. Dairy Sci. 67:1725-1738.

Sauer, F. D., V. Fellner, R. Kinsman, J. K. G. Kramer, H. A. Jackson, A. J. Lee, and S. Chen. 1998. Methane output and lactation response in Holstein cattle with monensin or unsaturated fat added to the diet. J. Anim. Sci. 76:906-914.

Schwab, C. G., P. Huhtanen, C. W. Hunt, and T. Hvelplund. 2005. Nitrogen requirements of cattle. Pages 13-70 in Nitrogen and Phosphorus Nutrition of Cattle and Environment. E. Pfeffer and A. N. Hristov, ed. CAB International, Wallingford, UK.

Sjaunja, L. O., L. Baevre, L. Junkkarinen, J. Pedersen, and J. Setälä. 1990. A Nordic proposal for an energy corrected milk (ECM) formula. Pages 156-157 in 27th Session of the International Commission for Breeding and Productivity of Milk Animals, Paris, France. Wageningen Academic Publishers, Wageningen, the Netherlands.

Socha, M. 1991. Effect of heat-processed whole soybeans on milk production, milk composition, and milk fatty acid profile. MS Thesis. Univ. of Wisconsin, Madison.

Solanas, E. M., C. Castrillo, M. Jover, and A. de Vega. 2008. Effect of extrusion on in situ ruminal protein degradability and in vitro digestibility of undegraded protein from different feedstuffs. J. Sci. Food Agric. 88:2589-2597.

Stewart, C. S., and H. J. Flint. 1989. Bacteroides (Fibrobacter) succinogenes, a cellulolytic anaerobic bacterium from the gastrointestinal tract. Appl. Microbiol. Biotechnol. 30:433-439. 